\title{
In Vivo Gene Transfection with Heat Shock Protein 70 Enhances Myocardial Tolerance to Ischemia-Reperfusion Injury in Rat
}

\author{
Ken Suzuki, Yoshiki Sawa, Yasufumi Kaneda, ${ }^{\star}$ Hajime Ichikawa, Ryota Shirakura, ${ }^{\ddagger}$ and Hikaru Matsuda \\ First Department of Surgery, *Institute for Cellular and Molecular Biology, and ${ }^{\ddagger}$ Division of Organ Transplantation of Biomedical \\ Research Center, Osaka University, Suita, Osaka, 565, Japan
}

\begin{abstract}
Heat shock protein 70 (HSP70) has been reported to be involved in the myocardial self-preservation system. To obtain the evidence that HSP70 plays a direct role in the protection from myocardial ischemia-reperfusion injury, rat hearts were transfected with human HSP70 gene by intracoronary infusion of hemagglutinating virus of Japan (HVJ)-liposome containing human HSP70 gene. The control hearts were infused with HVJ-liposome without the HSP70 gene. The hearts from whole-body heat-stressed or nontreated rats were also examined. Western blot and immunohistochemical analysis showed that apparent overexpression of HSP70 occurred in the gene transfected hearts and that gene transfection might be more effective for HSP70 induction than heat stress. In Langendorff perfusion, better functional recovery as well as less creatine phosphokinase leakage after ischemia were obtained in the gene transfected hearts with HSP70 than in the control or nontreated hearts. Furthermore, the gene transfected hearts showed better functional recovery than the heat-stressed hearts. These results indicated that overexpressed HSP70 plays a protective role in myocardial injury, suggesting the possibility that gene transfection with HSP70 may become a novel method for myocardial protection through enforcing the self-preservation systems. (J. Clin. Invest. 1997. 99: 1645-1650.) Key words: heat shock proteins - gene transfer • myocardial protection - ischemia-reperfusion injury • hemagglutinating virus of Japan
\end{abstract}

\section{Introduction}

Heat shock protein (HSP) $)^{1}$ is a self-preservation protein, which maintains cell homeostasis under environmental stress $(1,2)$. Of the various members of the HSP family, heat shock

Address correspondence to Hikaru Matsuda, M.D., Professor of First Department of Surgery, Osaka University, 2-2 Yamada-Oka, Suita, Osaka, 565, Japan. Phone: 81-6-879-3154; FAX: 81-6-879-3159; E-mail: matsuda@surg1.med.osaka-u.ac.jp

Received for publication 26 August 1996 and accepted in revised form 23 January 1997.

1. Abbreviations used in this paper: $\mathrm{CF}$, coronary flow; $\mathrm{CPK}$, creatine phosphokinase; HR, heart rate; HSP, heat shock protein; HSP70, heat shock protein 70; HVJ, hemagglutinating virus of Japan; LVDP, left ventricular developed pressure.

J. Clin. Invest.

(C) The American Society for Clinical Investigation, Inc.

0021-9738/97/04/1645/06 \$2.00

Volume 99, Number 7, April 1997, 1645-1650 protein 70 (HSP70) is strongly induced in the myocardium under various forms of stress, such as heat stress (3-6) or brief ischemia $(7,8)$. The heart with high level expression of HSP70 caused by the stress shows enhanced myocardial tolerance to ischemic injury, possibly through a chaperon function of HSP70 $(2,9,10)$. However, the protective effects may be contaminated by factors other than HSP70, because the stresses such as heat or ischemia also induce the increase in some other cytoprotective proteins, for example, catalase $(11,12)$, SOD (13), or other members of the HSP family (7). To dissect the direct role of HSP70 in the protection from myocardial injury in vivo, we consider that a method to alter genetic information, such as gene transfection or transgenic animals, might be suitable.

To establish a method of gene transfection for the heart, many trials with intravenous injection (14), direct injection (15, 16), or intracoronary infusion of a naked plasmid (17) have been made. Nevertheless, the method of gene transfection for the entire heart, which causes overexpression of a protein and modification of myocardial characteristics with high efficiency, has not been established. Recently we have developed and reported an efficient in vivo gene transfection method for an entire rat heart by intracoronary infusion of hemagglutinating virus of Japan (HVJ)-liposome (18). In this study we investigated whether the in vivo gene transfection with HSP70 could introduce overexpression of HSP70 in the myocardium and improve myocardial tolerance to ischemia-reperfusion injury.

\section{Methods}

Animal care. All studies were performed with the approval of the Committee for Animal Research Ethics, Osaka University Medical School.

Construction of the expression vector containing human HSP70 $c D N A$. Full-length of human HSP70 cDNA (19) was provided by Dr. Sue Fox and Dr. Richard Morimoto (Department of Biochemistry, Molecular Biology and Cell Biology, Northwestern University, Evanston, IL). It was cloned at the EcoRI/BamHI site of pcDNA3 which has a cytomegalovirus promoter (Invitrogen Corp., San Diego, CA).

Preparation of HVJ-liposome. The preparation of the HVJ-liposome has been described previously (20-24). Briefly, $10 \mathrm{mg}$ of lipid mixture (phosphatidylserine, phosphatidylcholine, and cholesterol) was deposited on the side of a flask by removing tetrahydrofuran in a rotary evaporator. The dried lipid was hydrated in $200 \mu \mathrm{l}$ of balanced salt solution $(137.0 \mathrm{mM} \mathrm{NaCl}, 5.4 \mathrm{mM} \mathrm{KCl}, 10.0 \mathrm{mM}$ Tris- $\mathrm{HCl}$; $\mathrm{pH}$ 7.6) containing a DNA $(200 \mu \mathrm{g})$-HMG1 (high mobility group $1 \mathrm{nu}-$ clear protein, $64 \mu \mathrm{g}$ ) complex. A liposome-DNA-HMG1 complex suspension was prepared by vortexing, sonication, and shaking to form liposome. The liposome suspension was incubated with 30,000 hemagglutinating units of $\mathrm{HVJ}$, which was inactivated by ultraviolet irradiation, first at $4^{\circ} \mathrm{C}$ and then at $37^{\circ} \mathrm{C}$. Finally, $4 \mathrm{ml}$ of the sucrose gradient layer containing $\mathrm{HVJ}$-liposome was collected for use.

Gene transfection by intracoronary infusion ( $H$ and $C$ groups). Gene transfection was performed to hearts of Sprague-Dawley rats $(250 \mathrm{~g})$ as described before (18). Briefly, the hearts were arrested with cold cardioplegia and removed under anesthesia with sodium 
pentobarbital (50 mg/kg, intraperitoneally) and anticoagulation with heparin (200 USP units, intravenously). The hearts from the group transfected with the HSP70 gene (H group, $n=13$ ) were infused with $1 \mathrm{ml}$ of HVJ-liposome containing pcDNA3 with human HSP70 cDNA via the coronary artery, with the vena cavas, pulmonary arteries, and veins ligated. The control hearts ( $\mathrm{C}$ group, $n=13$ ) were infused with the same volume of HVJ-liposome containing pcDNA3 but without the HSP70 gene. After incubation on ice for $10 \mathrm{~min}$, the hearts were then heterotopically transplanted into the abdomens of recipient rats $(350 \mathrm{~g})$ of the same strain (25). These rats were killed on the fourth day after gene transfection, thus allowing the introduced gene to express proteins stably and giving enough time for rat intrinsic HSP70 induced by the surgical stress to disappear.

Whole-body heat stress (S group). Sprague-Dawley rats (250 g, $n=13$ ) from the $\mathrm{S}$ group were exposed in a heat control box under general anesthesia with sodium pentobarbital $(50 \mathrm{mg} / \mathrm{kg}$, intraperitoneally). The rats were gradually heated up to $42^{\circ} \mathrm{C}$ under continuous monitoring of rectal temperature and kept at $42^{\circ} \mathrm{C}$ for $20 \mathrm{~min}$, which is reported to be the most effective setting for induction of HSP70 in rat heart (26). The rats were then taken out from the box and their surfaces were cooled to hasten recovery. In the early recovery period, the rats were given water orally to replenish fluid loss during heating. The rats were killed $24 \mathrm{~h}$ after whole-body heat stress (26) without transplantation.

Nontreated rats ( $N$ group). The hearts of nontreated SpragueDawley rats $(250 \mathrm{~g}, n=13)$ killed without transplantation were also examined ( $\mathrm{N}$ group).

Immunohistochemical analysis. Rats from the four groups $(\mathrm{H}, \mathrm{C}$, $\mathrm{S}$, and $\mathrm{N}$ groups; $n=5$ from each group) were anesthetized by diethyl ether inhalation and anticoagulated by intravenous injection of heparin. The hearts were removed and quickly divided into two parts. One part was immediately frozen in embedding medium, OCT compound (Miles Inc., Diagnostics Division, Elkhart, IN) with liquid nitrogen for immunohistochemical analysis. The samples were cut into thin sections $(5 \mu \mathrm{m})$. After blocking with $5 \%$ fetal bovine serum, the sections were incubated first with a 1:1,000 dilution of anti-human HSP70 monoclonal antibody, SPA-810 (Stress Gen Biotechnologies Corp., Victoria, British Columbia, Canada), followed by incubation with a 1:180 dilution of FITC-conjugated goat anti-mouse IgG monoclonal antibody (Medical \& Biological Laboratories Co., Ltd., Nagoya, Japan). The sections were observed with a fluorescence microscope (PM-30, Olympus, Tokyo, Japan).

Western blot analysis. Western blot analysis was performed with two kinds of anti-HSP70 monoclonal antibody. One was MA3-009 (Affinity Bioreagents, Inc., Golden, $\mathrm{CO}$ ), which reacts with human HSP70 only. The other was SPA-810 (Stress Gen Biotechnologies Corp.), which reacts with both rat and human HSP70. The other parts of the hearts from the four groups was immediately frozen in liquid nitrogen, homogenized, and centrifuged. After determination of protein concentration with the bicinchoninic acid method, $100 \mu \mathrm{g}$ of proteins in each sample was loaded onto a 7.5\% SDS-PAGE system. The blots were transferred onto a PVDF membrane (Bio-Rad Laboratories, Richmond, CA) and incubated in Tris-buffered saline-Tween 20 (20.0 mM Tris- $\mathrm{HCl}$, pH 7.5, $150.0 \mathrm{mM} \mathrm{NaCl}, 0.05 \%$ Tween 20 ) containing $2 \%$ skim milk to block nonspecific binding sites. The membrane was immunoreacted with a 1:5,000 dilution of MA3-009 or a 1:1,000 dilution of SPA-810. Either membrane was then incubated with a 1:1,000 dilution of alkaline phosphatase-conjugated goat antimouse IgG antibody (Organon Teknika Corp., Durham, NC). Nitro blue tetrazolium and 5-bromo-4-chloro-3-indolyl phosphate were used as substrates for visualization of the reaction product. The degree of HSP70 expression was semiquantitatively evaluated with computed densitometry (NIH Image; Macintosh; Apple Computers, Cupertino, CA).

Myocardial tolerance to ischemia-reperfusion injury. The remaining rats from the four groups ( $n=8$ from each group) were anesthetized by diethyl ether inhalation and anticoagulated by intravenous injection of heparin. Their hearts were quickly excised and perfused with modified Krebs-Henseleit buffer $(120.0 \mathrm{mM} \mathrm{NaCl}, 4.5 \mathrm{mM} \mathrm{KCl}$, $20.0 \mathrm{mM} \mathrm{NaHCO}_{3}, 1.2 \mathrm{mM} \mathrm{KH}_{2} \mathrm{PO}_{4}, 1.2 \mathrm{mM} \mathrm{MgCl}_{2}, 2.5 \mathrm{mM} \mathrm{CaCl}_{2}$, and $10.0 \mathrm{mM}$ glucose; gassed with $95 \% \mathrm{O}_{2}+5 \% \mathrm{CO}_{2}$ to obtain $\mathrm{pH}$ 7.4 at $37^{\circ} \mathrm{C}$ ) at a pressure equal to $1 \mathrm{~m} \mathrm{H}_{2} \mathrm{O}$ by means of a Langendorff apparatus. A thin-wall latex balloon was inserted into the left ventricle through the left atrium to monitor left ventricular pressure and control left ventricular volume. After stabilization, heart rate (HR), left ventricular developed pressure (LVDP), maximum $\mathrm{dP} / \mathrm{dt}$ (max $\mathrm{dP} / \mathrm{dt})$, minimum $\mathrm{dP} / \mathrm{dt}(\min \mathrm{dP} / \mathrm{dt})$, and coronary flow $(\mathrm{CF})$ were measured with LV diastolic pressure stabilized at $10 \mathrm{mmHg}$. The hearts were then subjected to global ischemia at $37^{\circ} \mathrm{C}$ for $30 \mathrm{~min}$, followed by 60 min of reperfusion. The balloon was deflated during ischemia. The indices of cardiac function were continuously measured after reperfusion and analyzed. Before ischemia and at 5, 10, $20,30,40,50$, and $60 \mathrm{~min}$ of reperfusion, the coronary effluent was collected in chilled vials to measure creatine phosphokinase (CPK) leakage.

Statistical analysis. All values are expressed as means \pm SEM. The differences in the data on functional recoveries or CPK leakage within groups were determined with one-way repeated-measures ANOVA. If a significant $F$ ratio was obtained, further comparisons were determined with Bonferroni/Dunn post-hoc test. All analyses were performed using the Statview v4.0 statistical package (Abacus Concepts Inc., Berkeley, CA). A value of $P<0.05$ was considered statistically significant.

\section{Results}

The mortality in the gene transfection method. There was no technical failure or operative death in the 26 consecutive trials for gene transfection ( $\mathrm{H}$ and $\mathrm{C}$ groups) in the study.

Western blot analysis. Western blot analysis using MA3009, which reacts only with human HSP70, indicated apparent expression of human HSP70 in the $\mathrm{H}$ group alone (Fig. 1). Western blot analysis using SPA-810, which reacts with both rat and human HSP70, indicated stronger expression of HSP70 in the $\mathrm{H}$ or $\mathrm{S}$ group than in the $\mathrm{C}$ or $\mathrm{N}$ group (Fig. 2). According to semiquantitative analysis with computed densitometry, the $\mathrm{H}$ group showed 12-20 times more, while the $\mathrm{S}$ group showed 8-11 times more HSP70 than the C group did. A comparison between the $\mathrm{H}$ and $\mathrm{S}$ groups suggested that the $\mathrm{H}$ group might have the potential to express larger amounts of HSP70 than did the S group.

Immunohistochemical analysis. An immunohistochemical examination with anti-HSP70 monoclonal antibody showed apparent and extensive overexpression of HSP70 in the cytoplasm of cardiomyocytes in the hearts from the $\mathrm{H}$ group (Fig. 3, left) as compared with those from the $\mathrm{C}$ group (Fig. 3, right).

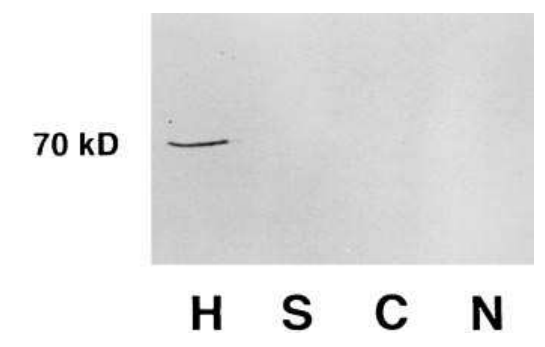

Figure 1. Western blot analysis with MA3-009. Overexpression of HSP70 was checked with Western blot with MA3-009. MA3-009 is an anti-HSP70 monoclonal antibody, showing a reaction with only human HSP70. Appar-

ent expression of human HSP70 was observed only in the $\mathrm{H}$ group. $\mathrm{H}$ group, gene transfected hearts with HSP70; S group, heat-stressed hearts; $\mathrm{C}$ group, control transfected hearts; $\mathrm{N}$ group, nontreated hearts. 


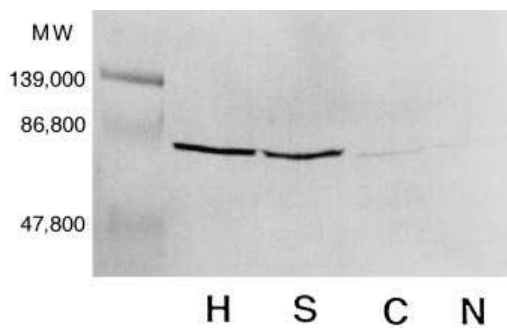

Stronger expression of HSP70 was observed in the in the $\mathrm{C}$ or $\mathrm{N}$ group. The $\mathrm{H}$ group appeared to express larger amounts of HSP70 than did the S group. $M W$, molecular weight. H group, gene transfected hearts with HSP70; S group, heat-stressed hearts; C group, control transfected hearts; $\mathrm{N}$ group, nontreated hearts.

When the cells showing clearly stronger fluorescence than those in the $\mathrm{C}$ group (as shown in Fig. 3) were considered as overexpressing HSP70, 50-70\% of the cardiomyocytes in all hearts from the $\mathrm{H}$ group were seen to overexpress HSP70.

Myocardial tolerance to ischemia-reperfusion injury. In the perfused heart experiment, no significant difference was seen before ischemia among the groups $(n=8$ in each group, Table I) in terms of HR, LVDP, $\max \mathrm{dP} / \mathrm{dt}$, min $\mathrm{dP} / \mathrm{dt}$, and $\mathrm{CF}$.
Table I. Cardiac Parameters before Ischemia in Langendorff Perfusion

\begin{tabular}{lcccccc}
\hline Group $n$ & HR & LVDP & $\max \mathrm{dP} / \mathrm{dt}$ & $\min \mathrm{dP} / \mathrm{dt}$ & $\mathrm{CF}$ \\
\hline & & beats $/ \mathrm{min}$ & $m m H g$ & $m m H g / s$ & $m m H g / s$ & $\mathrm{ml} / \mathrm{min}$ \\
$\mathrm{H}$ & 8 & $278.0 \pm 8.9$ & $100.4 \pm 5.9$ & $1301.3 \pm 78.8$ & $-1190.6 \pm 66.1$ & $19.0 \pm 1.0$ \\
$\mathrm{C}$ & 8 & $275.5 \pm 10.3$ & $102.6 \pm 5.7$ & $1326.3 \pm 80.6$ & $-1177.5 \pm 69.4$ & $18.9 \pm 1.0$ \\
$\mathrm{~S}$ & 8 & $299.5 \pm 7.7$ & $110.4 \pm 6.6$ & $1525.0 \pm 82.9$ & $-1300.0 \pm 69.4$ & $19.8 \pm 1.8$ \\
$\mathrm{~N}$ & 8 & $304.5 \pm 8.7$ & $111.6 \pm 4.8$ & $1518.1 \pm 76.3$ & $-1293.8 \pm 74.7$ & $19.3 \pm 1.3$
\end{tabular}

Data are expressed as mean \pm SEM. There was no significant difference in any parameter among the groups before ischemia $(P<0.05) . n$, number of samples.

The time course of percent recovery of LVDP after global ischemia $\left(37^{\circ} \mathrm{C}, 30 \mathrm{~min}\right)$ was shown in Fig. 4. The percent recovery of LVDP after ischemia in the nontreated hearts $(\mathrm{N}$ group) and control transfected hearts ( $\mathrm{C}$ group) reached the peak values (41.3 \pm 5.1 and $42.1 \pm 4.4 \%$, respectively) $40 \mathrm{~min}$ after the onset of reperfusion. There was no significant difference in the recovery of LVDP between the nontreated hearts and control transfected hearts. In comparison with the non-
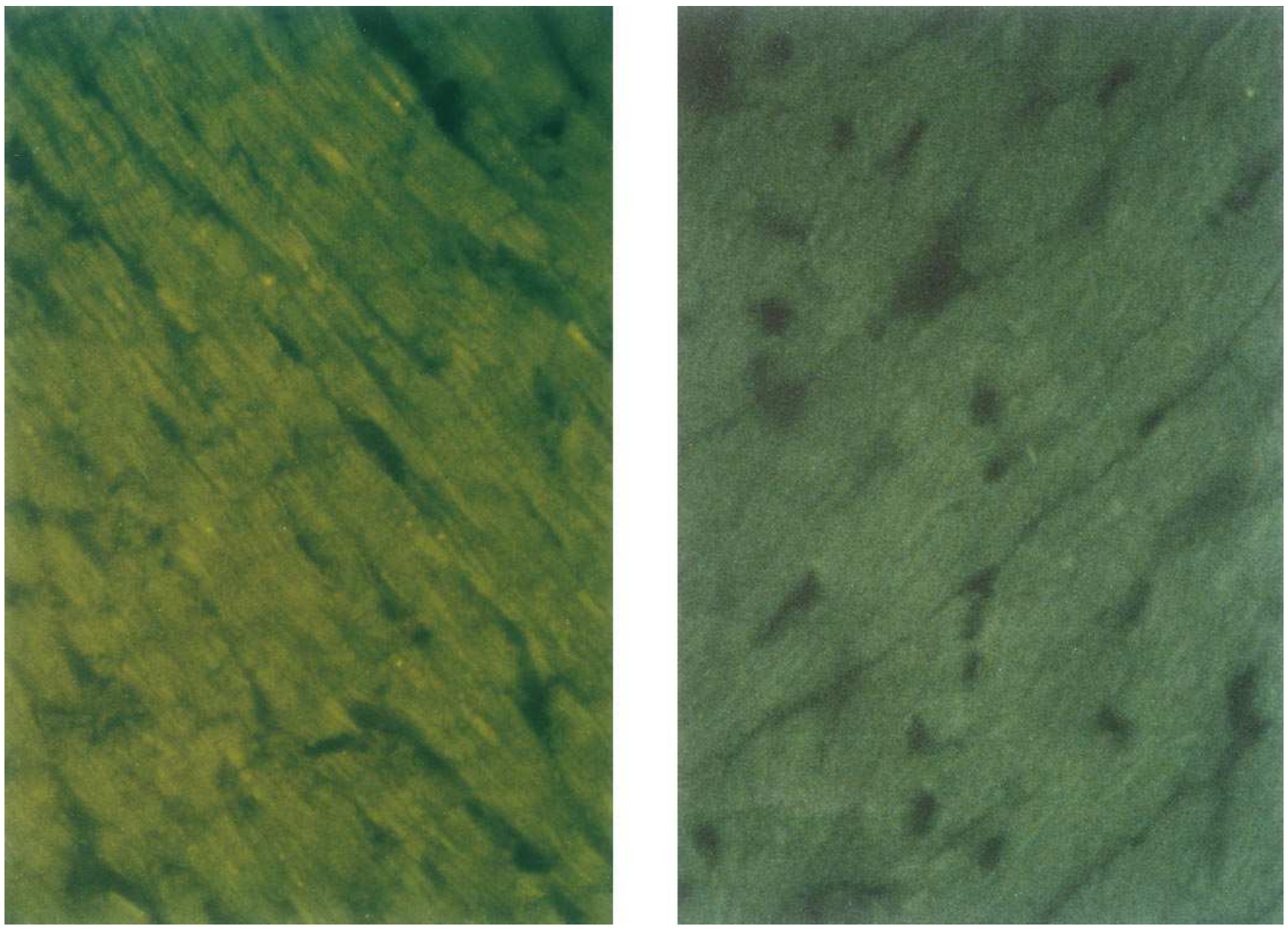

Figure 3. Immunohistochemical analysis for HSP70. Overexpression of HSP70 was investigated with immunohistochemistry. Overexpression of HSP70 was observed in the cytoplasm of cardiomyocytes widely in the hearts from the $\mathrm{H}$ group $(l e f t, \times 200)$, as compared with those from the $\mathrm{C}$ group $($ right,$\times 200)$. 


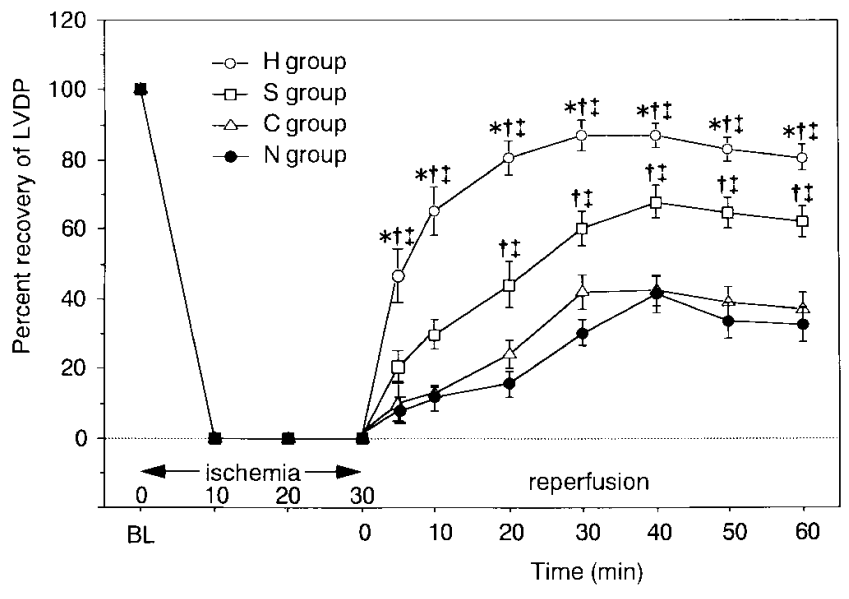

Figure 4. Recovery of LVDP after ischemia. The isolated hearts from the four groups were subjected to $30 \mathrm{~min}$ of normothermic global ischemia followed by $60 \mathrm{~min}$ of reperfusion. Better recovery of LVDP after ischemia was shown in the $\mathrm{H}$ group than in the $\mathrm{C}, \mathrm{N}$, or $\mathrm{S}$ group. The $\mathrm{S}$ group showed better recovery of LVDP than the $\mathrm{C}$ or $\mathrm{N}$ group did. Data are expressed as percentage of basal LVDP before ischemia. $B L$, base line. ${ }^{*} P<0.05$ vs. $\mathrm{S}$ group; ${ }^{\dagger} P<0.05$ vs. C group; ${ }^{\ddagger} P<0.05$ vs. $\mathrm{N}$ group, $n=8$ in each group. All values are expressed as mean $\pm \mathrm{SEM}$.

treated or control transfected hearts, a significant improvement of the percent recovery of LVDP was observed in the heat-stressed hearts (S group), which also reached the peak level $(67.6 \pm 4.7 \%)$ at $40 \mathrm{~min}$ of reperfusion. The percent recovery of LVDP was significantly best in the gene transfected hearts with HSP70 ( $\mathrm{H}$ group) throughout the reperfusion period. The peak percent recovery of LVDP in the gene transfected hearts with HSP70 $(86.9 \pm 4.3 \%)$ was encountered at 30 min of reperfusion which was earlier than that of other three groups. Although there was no statistical significance, the percent recoveries of LVDP tended to decline after they peaked in all groups examined.

The time courses of recoveries of max and min $\mathrm{dP} / \mathrm{dt}$ after global ischemia were shown in Fig. 5. The heat-stressed hearts showed significantly better recoveries of $\max$ and $\min \mathrm{dP} / \mathrm{dt}$

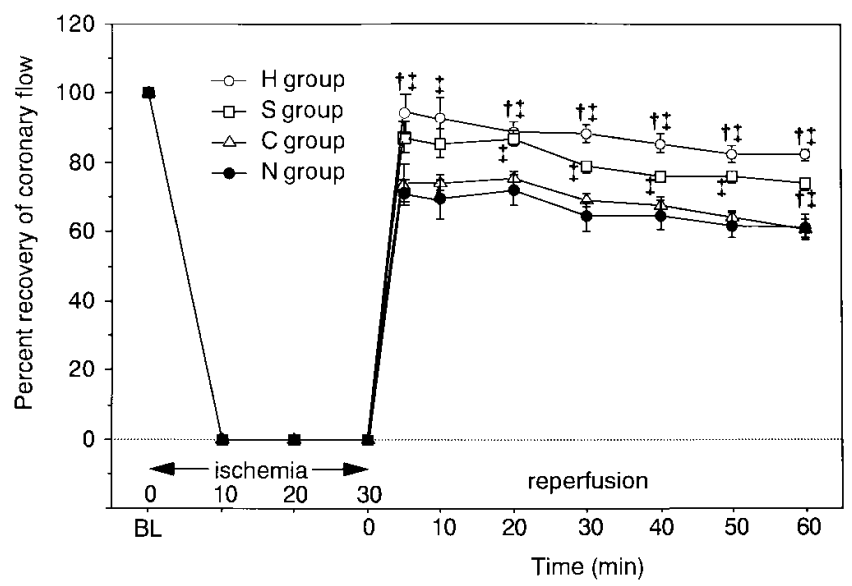

Figure 6. Recovery of CF after ischemia. Better recovery of CF after 30 min of normothermic global ischemia was shown in the $\mathrm{H}$ group than in the $\mathrm{C}$ or $\mathrm{N}$ group. The $\mathrm{S}$ group showed better recovery of $\mathrm{CF}$ than the $\mathrm{C}$ or $\mathrm{N}$ group did. Data are expressed as percentage of basal CF before ischemia. $B L$, base line. ${ }^{\dagger} P<0.05$ vs. C group; ${ }^{\ddagger} P<0.05$ vs. $\mathrm{N}$ group, $n=8$ in each group. All values are expressed as mean \pm SEM.

than both the control transfected and nontreated hearts did. However, much better recoveries of max and $\min \mathrm{dP} / \mathrm{dt}$ were obtained in the gene transfected hearts with HSP70 in comparison with the heat-stressed, control transfected, or nontreated hearts. The peak values both of max and $\min \mathrm{dP} / \mathrm{dt}$ were observed $>30 \mathrm{~min}$ after reperfusion in all four groups. The peak values of max and $\min \mathrm{dP} / \mathrm{dt}$ were $85.4 \pm 5.1$ and $82.9 \pm 3.8 \%$ in the gene transfected hearts with HSP70, 64.3 26.7 and $65.8 \pm 6.7 \%$ in the heat-stressed hearts, $38.1 \pm 4.2$ and $36.1 \pm 3.6 \%$ in the control transfected hearts, and finally $27.5 \pm 4.5$ and $31.4 \pm 4.3 \%$ in the nontreated hearts.

As for the recovery of CF (Fig. 6), both the gene transfected hearts with HSP70 and heat-stressed hearts showed better recovery after ischemia as compared with the control transfected and nontreated hearts. The recovery of CF in the control transfected and nontreated hearts reach the peaks 20
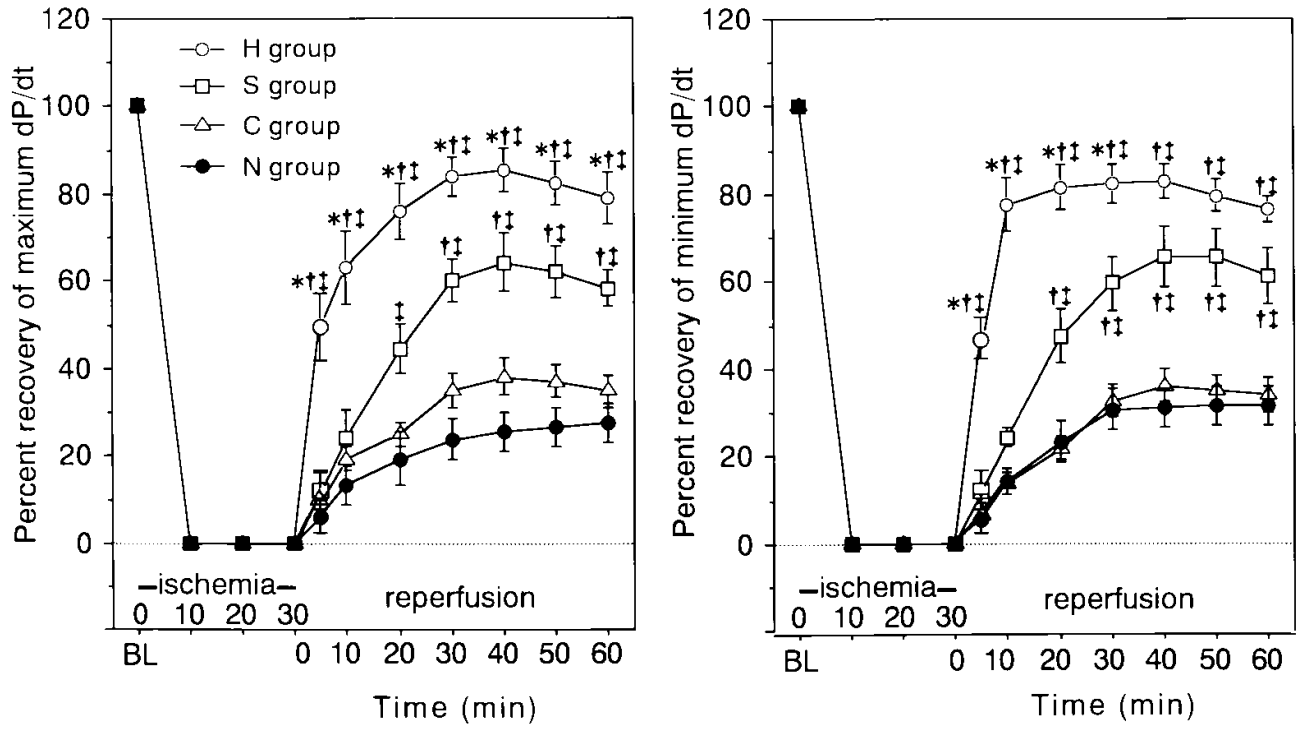

Figure 5. Recovery of maximum and minimum $\mathrm{dP} / \mathrm{dt}$ after ischemia. Better recovery of both maximum (max) and minimum (min) dP/dt after $30 \mathrm{~min}$ of normothermic global ischemia was shown in the $\mathrm{H}$ group than in the $\mathrm{C}, \mathrm{N}$, or $\mathrm{S}$ group. The $\mathrm{S}$ group showed better recovery of both max and min $\mathrm{dP} / \mathrm{dt}$ than the $\mathrm{C}$ or $\mathrm{N}$ group did. Data are expressed as percentage of basal max and min $\mathrm{dP} / \mathrm{dt}$ before ischemia. $B L$, base line. ${ }^{*} P<0.05$ vs. $S$ group; ${ }^{\dagger} P<$ 0.05 vs. $C$ group; ${ }^{\ddagger} P<0.05$ vs. $\mathrm{N}$ group, $n=8$ in each group. All values are expressed as mean \pm SEM. 


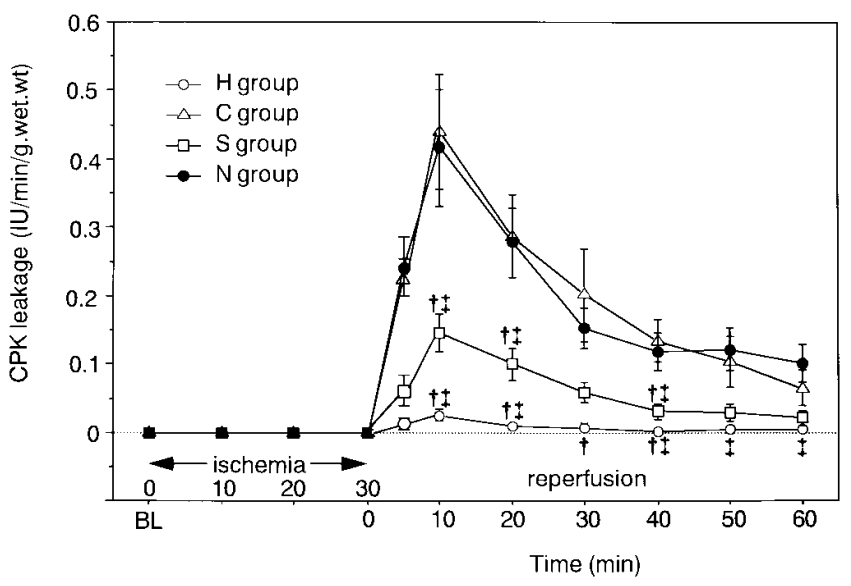

Figure 7. CPK leakage after ischemia. CPK in coronary effluent from isolated rat hearts was measured before and after ischemia. CPK leakage was more reduced in the $\mathrm{H}$ or $\mathrm{S}$ group than in the $\mathrm{C}$ or $\mathrm{N}$ group. $B L$, base line. ${ }^{\dagger} P<0.05$ vs. C group; ${ }^{\ddagger} P<0.05$ vs. $\mathrm{N}$ group, $n=8$ in each group. All values are expressed as mean \pm SEM.

min after the onset of reperfusion $(75.3 \pm 2.0$ and $72.1 \pm 4.4 \%$, respectively), whereas, in the gene transfected hearts with HSP70 and heat-stressed hearts, it reached the maximum level at $5 \mathrm{~min}$ of reperfusion $(92.8 \pm 5.8$ and $87.0 \pm 2.2 \%$, respectively). The recovery of CF in the gene transfected hearts with HSP70 tended to be higher than that in the heat-stressed hearts.

The time course of CPK leakage after ischemia in the four groups (shown as IU/min/g of wet weight) is presented in Fig. 7. CPK in coronary effluent from isolated rat hearts was not detected before ischemia in any group. CPK leakage after ischemia was significantly reduced in both the gene transfected hearts with HSP70 and heat-stressed hearts than in the control and nontreated hearts. The peak levels of CPK leakage were observed $10 \mathrm{~min}$ after the onset of reperfusion in all four groups examined. The peak value was $0.025 \pm 0.008 \mathrm{IU} / \mathrm{min} / \mathrm{g}$ of wet weight in the gene transfected hearts, $0.145 \pm 0.028 \mathrm{IU} /$ $\mathrm{min} / \mathrm{g}$ of wet weight in the heat-stressed hearts, $0.416 \pm 0.085$ $\mathrm{IU} / \mathrm{min} / \mathrm{g}$ of wet weight in the nontreated hearts, and $0.439 \pm 0.083 \mathrm{IU} / \mathrm{min} / \mathrm{g}$ of wet weight in the control transfected hearts. Although CPK leakage tended to be less in the gene transfected hearts with HSP70 than in the heat-stressed hearts throughout the reperfusion period, the difference was not statistically significant.

There were no significant differences in the percent recovery of HR among the groups. No significant difference was seen between the $\mathrm{C}$ and $\mathrm{N}$ groups in the recovery of any of the cardiac parameters after ischemia-reperfusion.

\section{Discussion}

In in vitro situations, many experiments using gene transfection techniques have suggested the direct role of overexpressed HSP70 in the protection from some types of injury in various cells (27-29). In this study, we demonstrated that the rat hearts transfected with human HSP70 gene showed apparent and global overexpression of HSP70 in the myocardium. The hearts, which overexpressed HSP70 as a result of gene transfection, showed enhanced recovery of both systolic and diastolic cardiac functions as well as less myocardial damage after is- chemia-reperfusion as compared with the control or nontreated hearts. These findings appear to provide the evidence that overexpressed HSP70 plays a direct role in the enhancement of myocardial tolerance in vivo. This is consistent with the results of an analysis using transgenic mice overexpressing HSP70 $(30,31)$. In a transgenic animal, however, the heart is genetically altered to overexpress HSP70, so that it may adapt itself to a situation overexpressing HSP70 and develop the character different from that of the natural heart. Therefore, the present model with gene transfection might be more suitable for investigating the effect of HSP70 in the natural myocardium.

In this present study, we developed a novel system to confirm the evidence of cardioprotective role of HSP70 in ischemic injury. It is a combination of intracoronary infusion of HVJ-liposome and heart transplantation to transfer HSP70 gene, followed by Langendorff perfusion to evaluate the effect of HSP70 on myocardial protection. We think this is a simple and reliable system to investigate the effect of each molecule on myocardial ischemia-reperfusion injury in an in vivo situation.

This study demonstrated that the gene transfection had a potential to introduce larger amounts of HSP70 and to enhance myocardial tolerance to ischemia better than the heat stress. This indicates that the super high level expression of HSP70 induced by gene transfection is more effective to protect myocardium from ischemia-reperfusion injury as compared with many self-protective mechanisms mobilized by heat stress containing the normal high level of expression of HSP70 (7, 11-13). It is also reported that the amount of HSP70 expression correlates well with the protective effect caused by heat stress $(26,27)$. Therefore, we consider that HSP70 is by far the most powerful and effective mechanism for myocardial protection among many endogenous protective mechanisms mobilized by heat stress.

In the field of cardiology, treatment for myocardial ischemia-reperfusion injury is a major concern. Developing the treatment will contribute to myocardial protection during treatment for acute myocardial infarction (including percutaneous transluminal coronary angioplasty or recanalization), cardiac surgery, or heart transplantation. Numerous previous attempts to attenuate myocardial damage with pharmacological agents have shown limitations. It has been revealed that self-preservation systems are involved in the mechanism of recovery from myocardial damage $(1,2)$. We consider that strengthening the self-preservation systems may lead to acquisition of more natural myocardial tolerance than with pharmacological approaches. Therefore, reinforcing the HSP70 induction could be a hopeful candidate for the more advanced method for myocardial protection. However, earlier methods to induce HSP70 seem to have involved some difficulties for clinical application. Whole-body heat stress (3-6) or drug administration (32) may cause harmful side effects in other organs, such as the cerebral system. Moreover, these methods have resulted in only a short induction of HSP70 (a few days).

On the other hand, our gene transfection method could cause a protein to overexpress without myocardial damage or

2. $\beta$-Galactosidase expression was observed in rat heart for $>2 \mathrm{wk}$ after in vivo gene transfection by intracoronary infusion of HVJ-liposome. 
harmful side effects in other organs $(18,21-24)$. As was shown in this study, the gene transfection method showed a potential to introduce larger amounts of HSP70 and to enhance myocardial tolerance to ischemia better than did heat stress $\left(42^{\circ} \mathrm{C}, 20\right.$ $\min )$. We speculate that the duration of the protein overexpression by our gene transfection method may be at least a few weeks from our unpublished data $^{2}$ on $\beta$-galactosidase expression and the results in other organs (22-24). Accordingly, gene transfection may be expected to continue overexpressing HSP70 much longer than methods such as heat stress. Therefore, gene transfection appears to be more effective and advantageous when applying HSP70 to clinical treatment. We consider that gene transfection with HSP70 may become an advanced myocardial protection method resulting from enhancing the self-preservation systems. For this purpose, however, much further investigation and improvement remain necessary.

In summary, the in vivo gene transfection by means of intracoronary infusion of HVJ-liposome caused overexpression of HSP70 in rat heart, resulting in enhancement of myocardial tolerance to ischemia-reperfusion injury. These data indicate a direct role of overexpressed HSP70 in preventing the ischemic injury in myocardium, suggesting a possibility that gene transfection with HSP70 may become a novel method for myocardial protection through endogenous route.

\section{Acknowledgments}

The authors would like to thank Dr. Sue Fox and Dr. Richard Morimoto (Department of Biochemistry, Molecular Biology and Cell Biology, Northwestern University, Evanston, IL) for kindly providing the full length of human HSP70 cDNA (plasmid pH 2.3).

This work was supported by a Grant-in-Aid for Scientific Research in Japan. Dr. Ken Suzuki is a Research Fellow of the Japan Society for the Promotion of Science.

\section{References}

1. Lindquist, S., and E.A. Craig. 1988. The heat-shock proteins. Annu. Rev. Genet. 22:631-677.

2. Black, S.C., and B.R. Lucchesi. 1993. Heat shock proteins and the ischemic heart. An endogenous protective mechanism. Circulation. 87:10481050.

3. Currie, R.W. 1987. Effect of ischemia and perfusion temperature on synthesis of stress-induced (heat shock) proteins in isolated and perfused rat hearts. J. Mol. Cell. Cardiol. 19:795-808.

4. Currie, R.W., R.M. Tanguay, and J.G. Kingma. 1993. Heat shock response and limitation of tissue necrosis during occlusion/reperfusion in rabbit hearts. Circulation. 87:963-971.

5. Yellon, D.M., E. Pasini, A. Cargnoni, M.S. Marber, D.S. Latchman, and R. Ferrari. 1992. The protective role of heat stress in the ischemic and reperfused rabbit myocardium. J. Mol. Cell. Cardiol. 24:895-907.

6. Walker, D.M., E. Pasini, S. Kucukoglu, M.S. Marber, E. Iliodromitis, R. Ferrari, and D.M. Yellon. 1993. Heat stress limits infarct size in the isolated perfused rabbit heart. Cardiovasc. Res. 27:962-967.

7. Marber, M.S., D.S. Latchman, J.M. Walker, and D.M. Yellon. 1993. Cardiac stress protein elevation 24 hours after brief ischemia or heat stress is associated with resistance to myocardial infarction. Circulation. 88:1264-1272.

8. Knowlton, A.A., P. Brecher, and C.S. Apstein. 1991. Rapid expression of heat shock protein in the rabbit after brief cardiac ischemia. J. Clin. Invest. 87: 139-147.

9. Ang, D., K. Liberek, D. Skowyra, M. Zylicz, and C. Georgopoulos. 1991. Biological role and regulation of the universally conserved heat shock proteins.
J. Biol. Chem. 266:24233-24236.

10. Yellon, D.M., and D.S. Latchman. 1992. Stress proteins and myocardial protection. J. Mol. Cell. Cardiol. 24:113-124.

11. Currie, R.W., and R.M. Tanguay. 1991. Analysis of RNA for transcripts for catalase and SP71 in rat hearts after in vivo hyperthermia. Biochem. Cell. Biol. 69:375-382.

12. Wall, S.R., H. Fliss, and B. Korecky. 1993. Role of catalase in myocardial protection against ischemia in heat shocked rats. Mol. Cell. Biochem. 129: 187-194.

13. Liu, X., R.M. Engelman, I.I. Moraru, J.A. Rousou, J.E. Flack, D.W. Deaton, N. Maulik, and D.K. Das. 1992. Heat shock. A new approach for myocardial preservation in cardiac surgery. Circulation. 86:358-363.

14. Stratford-Perricaudet, L.D., I. Makeh, M. Perricaudet, and P. Briand. 1992. Widespread long-term gene transfer to mouse skeletal muscles and heart. J. Clin. Invest. 90:626-630.

15. Lin, H., M.S. Parmacek, G. Morle, S. Bolling, and J.M. Leiden. 1990. Expression of recombinant genes in myocardium in vivo after direct injection of DNA. Circulation. 82:2217-2221.

16. French, B.A., W. Mazur, R.S. Geske, and R. Bolli. 1994. Direct in vivo gene transfer into porcine myocardium using replication-deficient adenoviral vectors. Circulation. 90:2414-2424.

17. Ardehali, A., A. Fyfe, H. Lanks, D.C. Drinkwater, J.H. Qiao, and A.J. Lusis. 1995. Cardiac and pulmonary replacement. Direct gene transfer into donor hearts at the time of harvest. J. Thorac. Cardiovasc. Surg. 109:716-720.

18. Sawa, Y., K. Suzuki, H.Z. Bai, R. Shirakura, R. Morishita, Y. Kaneda, and H. Matsuda. 1995. Efficiency of in vivo gene transfection into transplanted red heart by coronary infusion of HVJ-liposome. Circulation. 92(Suppl. II):479482.

19. Wu, B., C. Hunt, and R. Morimoto. 1985. Structure and expression of the human gene encoding major heat shock protein HSP70. Mol. Cell. Biol. 5: 330-341.

20. Kaneda, Y. 1994. Virus (Sendai virus envelopes)-mediated gene transfer. In Cell Biology, a Laboratory Handbook. J.E. Celis, editor. Academic Press, New York. Vol III. 50-57.

21. Kaneda, Y., K. Iwai, and T. Uchida. 1989. Increased expression of DNA cointroduced with nuclear protein in adult rat liver. Science (Wash. DC). 243: $375-378$.

22. Nakamura, N., S. Horibe, N. Matsumoto, T. Tomita, T. Natsuume, Y Kaneda, K. Shino, and T. Ochi. 1996. Transient introduction of a foreign gene into healing rat patellar ligament. J. Clin. Invest. 97:226-231.

23. Morishita, R., G.H. Gibbons, K.H. Ellison, M. Nakajima, L. Zhang, Y. Kaneda, T. Ogihara, and V.J. Dzau. 1993. Single intraluminal delivery of antisense cdc 2 kinase oligonucleotides results in chronic inhibition of neointimal hyperplasia. Proc. Natl. Acad. Sci. USA. 90:8474-8478.

24. Isaka, Y., Y. Fujiwara, N. Ueda, Y. Kaneda, T. Kamada, and E. Imai. 1993. Glomerulosclerosis induced by in vivo transfection of transforming growth factor- $\beta$ or platelet-derived growth factor gene into the rat kidney. $J$. Clin. Invest. 92:2597-2601.

25. Ono, K., and E. Lindsey. 1969. Improved technique of heart transplantation in rats. J. Thorac. Cardiovasc. Surg. 57:225-229.

26. Hutter, M.M., R.E. Sievers, V. Barbosa, and C.L. Wolfe. 1994. Heat shock protein induction in rat heart. A direct correlation between the amoun of heat-shock protein induced and the degree of myocardial protection. Circulation. 89:355-360.

27. Li, G.C., L. Li, Y.K. Liu, J.Y. Mak, L.W. Chen, and M.F. Lee. 1991 Thermal response of rat fibroblasts stably transfected with the human $70-\mathrm{kDa}$ heat shock protein-encoding gene. Proc. Natl. Acad. Sci. USA. 88:1681-1685.

28. Heads, R., D.S. Latchman, and D.M. Yellon. 1994. Stable high level expression of a heart-derived muscle cell line against thermal stress. J. Mol. Cell. Cardiol. 26:695-699.

29. Mestril, R., S.H. Chi, M.R. Sayen, K. O'Reilly, and W.H. Dillmann. 1994. Expression of inducible stress protein 70 in rat heart myogenic cells confers protection against simulated ischemia-induced injury. J. Clin. Invest. 93: 759-767.

30. Marber, M.S., R. Mestril, S.H. Chi, R. Sayen, D.M. Yellon, and W.H. Dillmann. 1995. Overexpression of the rat inducible 70-kD heat stress protein in a transgenic mouse increases the resistance of the heart to ischemic injury. $J$. Clin. Invest. 95:1446-1456.

31. Plumier, J.C.L., B.M. Ross, R.W. Currie, C.E. Angelidis, H. Kazlaris, G. Kollias, and G.N. Pagoulatos. 1995. Transgenic mice expressing the human heat shock protein 70 have improved postischemic myocardial recovery. J. Clin. Invest. 95:1854-1860.

32. Huber, S.A. 1992. Heat-shock protein induction in adriamycin and picornavirus-infected cardiomyocytes. Lab. Invest. 67:218-224. 